\title{
Toxicity Evaluation to Mice of Phylloseptin-1, an Antimicrobial Peptide from the Skin Secretion of Phyllomedusa hypochondrialis (Amphibia)
}

\author{
Selma Kückelhaus, ${ }^{1,5}$ José Roberto S. A. Leite, ${ }^{2,3}$ Mateus P. Neves, ${ }^{1}$ Karla S. Frota, ${ }^{1}$ Lídia \\ F. Abdala, ${ }^{4}$ Maria Imaculada Muniz-Junqueira, ${ }^{1}$ Carlos Bloch $\mathrm{Jr}^{3}{ }^{3}$ and Carlos Eduardo Tosta ${ }^{1}$
}

\begin{abstract}
The growing resistance of microorganisms to antibiotics has been considered as a global public health problem. Therefore, the search for novel antimicrobial drugs, chemically unrelated to the presently used antibiotics, is urgently needed. Our group has recently characterized a new family of antimicrobial peptides - phylloseptins - isolated from the skin secretion of the South American amphibian Phyllomedusa hypochondrialis, which showed a strong antimicrobial effect against Gram-positive and Gram-negative bacteria. We now investigate the in vivo toxicity of synthetic phylloseptin-1 (PS-1) toward bone marrow, liver, spleen, kidney and lung after endovenous administration to Swiss mice of a bolus dose of $4 \mathrm{mg} / \mathrm{kg}$. Genotoxicity was evaluated by quantifying erythrocyte micronuclei. PS-1-treated mice showed no alteration in the histology of liver, spleen, kidney and lung, as well as of blood biochemistry, as compared to normal controls. Cytotoxicity tests, evaluated either by blood cytometry or bone marrow polychromatophilic erythrocyte index, revealed no deleterious effect of PS-1. Moreover, the peptide showed no toxicity towards bone marrow erythrocytes. We concluded that, in a concentration ten times over that providing antimicrobial effect, synthetic PS-1 showed no in vivo toxicity.
\end{abstract}

KEY WORDS: phylloseptin-1; antimicrobial peptide; Phyllomedusa hypochondrialis; cytotoxicity; genotoxicity; mouse.

${ }^{1}$ Laboratório de Imunologia Celular, Área de Patologia, Faculdade de Medicina, Universidade de Brasília, Brasilia, DF, 70910900, Brazil.

${ }^{2}$ Campus Ministro Reis Velloso, Universidade Federal do PiauíUFPI, Parnaiba, PI, 64202-020, Brazil.

${ }^{3}$ Laboratório de Espectrometria de Massa, EMBRAPA/Recursos Genéticos e Biotecnologia, Brasilia, DF, 70910-900, Brazil.

${ }^{4}$ Laboratório Sabin de Análises Clínicas Ltda, Brasilia, DF, 70910-900, Brazil.

${ }^{5}$ Correspondence should be addressed to: Selma Kückelhaus, Laboratório de Imunologia Celular, Área de Patologia, Faculdade de Medicina, Universidade de Brasília, Brasilia, DF, 70910-900, Brazil. Tel.: + 55-61-33072273; Fax: + 5561-34356569; e-mail: selmak@unb.br.

\section{INTRODUCTION}

The growing emergence of resistance of microorganisms to antibiotics throughout the world, due to massive use and the occurrence of strongly selective environments for pathogens, such as the hospitals, lead the World Health Organization (WHO) to consider this phenomenon as a major public health problem (WHO, 2000). Therefore, the development of novel products or strategies became a central issue in the fight against pathogens (Black and Hodgson, 2005). In the last decades over 500 peptides with antimicrobial activity have been described (see http://aps.unmc.edu/AP/main.php), some of them were isolated from amphibians 
(Vanhoye et al., 2003). These animals are found to produce abundant active substances (Brand et al., 2002; Leite et al., 2005), ranging from biogenic amines, complex alkaloids, and antimicrobial peptides related to self-defence (Cunha Filho et al., 2005; Silva, 2004).

It is well established that antimicrobial peptides from amphibians are produced and stored in cutaneous granular glands, and are continuously released by holocrine mechanisms (Chen et al., 2003, 2005). These natural antimicrobial peptides confer protection against microorganisms, not only in the absence of a clonally based immune system, like in insects, but also in higher organisms, as an immediate host response to infections, well before the adaptive immune system is activated (Apponyi et al., 2004; Hancock and Diamond, 2000). These molecules are chemically unrelated to conventional antibiotics, making unlikely the emergence of crossresistant microorganisms. Moreover, amphibianderived antimicrobial peptides act directly on target cells by increasing membrane permeability in a way that does not appear to depend on specific receptors (Ambroggio et al., 2005; Matsuzaki, 1999; Peschel, 2002), and that is not affected by the resistance mechanisms presented by a growing number of pathogens towards antibiotics (Stark et al., 2002).

Several bioactive substances have been isolated from the skin secretions of amphibians belonging to the genus Phyllomedusa (subfamily Phyllomedusinae), which include dermaseptins (Brand et al., 2002; Krugliak et al., 2000; Mor et al., 1991; Shiri et al., 2002). Recently, our group identified a new family of six antimicrobial peptides called phylloseptins (PS) from the cutaneous secretion of Phyllomedusa hypochondrialis. The members of this family present activity against bacteria and fungi at micromolar concentrations (Leite et al., 2005). One of these is phylloseptin-1 (PS-1), a 19 amino-acidcationic peptide of $2016.14 \mathrm{Da}$, with amphiphilic properties, which showed a strong antimicrobial effect against Gram-positive and Gram-negative bacteria, and presented no significant hemolytic activity $(<0.6 \%$ at the MIC range) to mammalian erythrocytes (Leite et al., 2005). The aim of the present study was to evaluate the toxicity of synthetic PS-1 in an in vivo model, an essential step towards its possible future use in humans.

\section{MATERIAL AND METHODS}

\section{Phylloseptin-1 Solid Phase Synthesis}

Amidated PS-1 (FLSLIPHAINAVSAIAKHN-NH ${ }_{2}$ ) was synthesized on a Pioneer Synthesis System from Applied Biosystems (California, USA) (Merrifield, 1963). Fmoc amino acids and Fmoc-PALpoly (ethyleneglycol)-polystyrene (FmocPAL-PEG-PS) resin were purchased from Applied Biosystems (California, USA). A preparative C18 column Vydac 218 TP 1022 (Columbia, MD) on an HPLC system (Shimadzu Corporation, Kyoto, Japan) was used for purifying the product. Molecular mass and sample purity were checked by a Voyager DE MALDI-TOF/MS (PerSeptive Biosystems, Framingham, MA, USA) and MALDI TOF-TOF MS ULTRAFLEX II (Bruker Daltonics, Bremen, Germany).

\begin{abstract}
Animals
Female adult Swiss mice ( $n=8$ ), weighing $35-40 \mathrm{~g}$, obtained from the Centro Universitário de Brasília Animal House, received endovenously a bolus dose of PS-1 $(4 \mathrm{mg} / \mathrm{kg}$, a concentration 10 fold over its antimicrobial dose) in $100 \mu \mathrm{L}$ of $0.9 \% \mathrm{NaCl}$ solution, while the control group was treated with the same volume of the diluent. In the experiments on genotoxicity, mice were endovenously treated with a bolus dose of cyclophosphamide $(33 \mathrm{mg} / \mathrm{kg}$ ), a drug known for its clastogenic effect (Colvin and Chabner, 1990), and used as the positive control group. The animals were killed by ether inhalation after $24 \mathrm{~h}$ to 14 days, and several biological tests were performed using standard techniques. During the duration of experiments, mice were maintained at $12 \mathrm{~h}$ dark/light cycles, controlled temperature $\left(23^{\circ} \mathrm{C}\right)$, and received balanced food and water ad libitum.
\end{abstract}

\section{Cytotoxicity Assays}

Toxicity of PS-1 to blood cells was evaluated by quantification of total and differential peripheral blood leucocytes collected after treatment ( $24 \mathrm{~h}$ up to 14 days), or by the polychromatophilic bone marrow erythrocyte index ( 24 or $48 \mathrm{~h}$ ). Blood was collected in syringes previously treated with EDTA, and leucometry and leucogram were performed by standard techniques (Brillard and Mcdaniel, 1985). Bone marrow cells were collected from the femur, after cutting its extremities, with fetal calf serum, mechanically disrupted, distended on glass slide, fixed with absolute methanol, and stained with $15 \%$ Giemsa solution in phosphate-buffered saline $\mathrm{pH}$ 7.2. The polychromatophilic erythrocyte index (Bolliger, 2004) was calculated by assessing the ratio between polychromatophilic and normochromatophilic erythrocytes after examining 1000 cells.

\section{Genotoxicity Assay}

The possible clastogenic effect of PS- 1 was investigated by quantifying the total number of micronuclei in 1000 bone marrow polychromatophilic or normochromatophilic erythrocytes. Mice were divided into three groups of eight animals and received, by endovenous route, either a bolus dose of $4 \mathrm{mg} / \mathrm{kg}$ of PS-1 (test group), or $33 \mathrm{mg} / \mathrm{kg}$ of cyclophosphamide (Enduxan ${ }^{\circledR}$, Brasil) 
(positive control group), or $0.9 \% \mathrm{NaCl}$ solution (negative control group). The animals were killed 24 or $48 \mathrm{~h}$ after treatment, and bone marrow cells were collected, processed and examined as previously described.

\section{Biochemical Analysis}

The possible toxicity of PS-1 towards kidney and liver was evaluated by assessing the serum concentrations of urea, creatinine, aspartate aminotransferase (AST) and alanine-aminotransferase (ALT) (Moura, 1982). Groups of eight mice were treated with $100 \mu \mathrm{L}$ of either PS- $1(4 \mathrm{mg} / \mathrm{kg})$ or $0.9 \% \mathrm{NaCl}$ solution and killed after 24 or $48 \mathrm{~h}$. The analyses were made using the spectrophotometric system ADVIA 1650 (Bayer Corporation, Diagnostics Division, Tarrytown, USA).

\section{Histopathological Analysis}

Small fragments of liver, spleen, kidney and lung were collected and processed for histopathology following standard techniques (Clark, 1980), stained with hematoxylin and eosin and analysed by light microscopy. Photomicrographs were performed with a Sony Cyber shot camera model DSC-P72 of 3.2 megapixels (Tokio, Japan).

\section{Statistical Analysis}

The Kolmogorov-Smirnov test was used to evaluate the normality of the variables distribution, and the Kruskal-Wallis test followed by Dunn's method, to compare multiple unrelated nonnormal samples (Glantz, 1992). Differences with a two-tailed value of $p<0.05$ were considered statistically significant. The SigmaStat software (Jandel Scientific, San Rafael, CA) was used for statistical tests and the Microcal ${ }^{\mathrm{TM}}$ Origin $6.0{ }^{\circledR}$ software package (Microcal Software Inc., 1999) was employed for the graphic representations.

\section{RESULTS}

The determination of the $\mathrm{LD}_{50}$ of PS- 1 , with purity of $99.9 \%$, the dose able to kill $50 \%$ of the animals, is a usual step for toxicity studies. We administered doses from 4 to $32 \mathrm{mg} / \mathrm{kg}$ of PS- 1 to mice. This last concentration is equivalent 80 -fold over that able to provide in vitro antimicrobial effects $(\sim 4 \mu \mathrm{M})$. However, even at this high concentration, the peptide caused no death of injected animals or any morphological alterations (data not shown).

Endovenously administered PS-1 caused, in the time window used, no significant alteration in the total number of mouse peripheral blood leucocytes, as compared to the control group treated with $0.9 \%$ $\mathrm{NaCl}$ solution. This finding indicates that the peptide caused no in vivo inflammatory effect (Table I).
Erythrocyte toxicity, evaluated from the bone marrow polychromatophilic erythrocyte index, showed no in vivo effect of PS-1 when compared to that of the control group (Fig. 1). To evaluation of a possible clastogenic effect of PS-1 we utilized bone marrow immature erythrocytes. Both 24 and $48 \mathrm{~h}$ after treatment of mice with PS-1, the total number of micronuclei in erythrocytes were comparable to that of control mice treated with $0.9 \% \mathrm{NaCl}$ solution (Dunn's method, $p>0.05$ ), and lower than that caused by cyclophosphamide, a drug with known clastogenic effect (Fig. 2).

The evaluation of serum concentration of urea and creatinine gives a trusted indication of overall kidney function because, since these substances are normally filtered and excreted by the organ, an increased in their serum levels reflects a decline in the glomerular filtration rate. PS-1-treated mice showed serum levels of urea and creatinine comparable to those of the control group treated with $0.9 \% \mathrm{NaCl}$ solution (Dunn's method, $p>0.05$ ), which indicates no toxicity of PS-1 to the kidney (Fig. 3).

AST and ALT are cytosolic enzymes found in cells of several tissues, especially hepatocytes and muscle cells. These enzymes are released from damaged cells and are considered as useful tools for the diagnosis and monitoring of cell injury (Moura, 1982). We found that serum concentrations of AST and ALT in mice treated with PS-1 were comparable to those detected in control mice treated with $0.9 \%$ $\mathrm{NaCl}$ solution (Dunn's method, $p>0.05$ ), which indicates the toxicity absence of the peptide to liver and muscle cells (Fig. 4).

The histopathological evaluation of liver, spleen, kidney and lung by microscopy revealed no morphological alteration in mice treated with PS-1 in comparison to the control group treated with $0.9 \%$ $\mathrm{NaCl}$ (Fig. 5).

\section{DISCUSSION}

The results of the present investigation clearly indicate that, at a concentration 10-fold higher than that in which it presents an antimicrobial effect, endovenously administered PS-1 caused no detected toxic effect in mice, confirming the findings of Leite et al. (2005), using an in vitro system. At the same single concentration Ownby et al. (1997) have demonstrated the myotoxic effect of mellitin by dorsolateral injection on mice. 
Table I. Effects of phylloseptin-1 (PS-1), endovenously administered to mice ( $n=8)$, on the number and categories of peripheral blood leucocytes $($ cells $/ \mu \mathrm{L})$

\begin{tabular}{|c|c|c|c|c|c|c|}
\hline Time & Treatment & $\begin{array}{c}\text { Leucocytes }\left(\times 10^{2}\right) \\
\text { Median } \\
(25-75 \%)\end{array}$ & $\begin{array}{c}\text { Lymphocytes }\left(\times 10^{2}\right) \\
\text { Median } \\
(25-75 \%)\end{array}$ & $\begin{array}{c}\text { Neutrophils }\left(\times 10^{2}\right) \\
\text { Median } \\
(25-75 \%)\end{array}$ & $\begin{array}{c}\text { Monocytes }\left(\times 10^{2}\right) \\
\text { Median } \\
(25-75 \%)\end{array}$ & $\begin{array}{c}\text { Eosinophils }\left(\times 10^{2}\right) \\
\text { Median } \\
(25-75 \%)\end{array}$ \\
\hline \multirow[t]{2}{*}{$24 \mathrm{~h}$} & Saline & $72(65-79)$ & $56(50-63)$ & $7(5-9)$ & $6(5-10)$ & $0.8(0.3-1)$ \\
\hline & PS-1 & $82(67-106)$ & $60(45-76)$ & $6(2-1)$ & $9(3-16)$ & $1(1-2)$ \\
\hline \multirow[t]{2}{*}{$48 \mathrm{~h}$} & Saline & $66(58-70)$ & $54(50-59)$ & $5(4-6)$ & $2(2-4)$ & $0.3(0-0.7)$ \\
\hline & PS-1 & $65(61-69)$ & $57(54-61)$ & $3(2-6)$ & $1(1-2)$ & $0.1(0-0.3)$ \\
\hline \multirow[t]{2}{*}{7 days } & Saline & $69(64-75)$ & $54(50-65)$ & $5(4-7)$ & $7(3-8)$ & $0.3(0.3-0.9)$ \\
\hline & PS-1 & $68(64-79)$ & $54(49-67)$ & $5(3-6)$ & $8(6-10)$ & $1(0.4-1)$ \\
\hline \multirow[t]{2}{*}{14 days } & Saline & $75(60-91)$ & $66(55-77)$ & $5(3-8)$ & $7(5-8)$ & $1(0-0.9)$ \\
\hline & PS-1 & $86(70-94)$ & $71(53-79)$ & $9(7-10)$ & $4(3-8)$ & $1(0-0.6)$ \\
\hline
\end{tabular}

The time windows varied from $24 \mathrm{~h}$ to 14 days after a bolus dose of $4 \mathrm{mg} / \mathrm{kg}$ of PS- 1 or $0.9 \% \mathrm{NaCl}$ solution (Saline). The differences between groups were analysed by the Kruskal-Wallis test, followed by Dunn's method for multiple comparisons. No difference between groups was found.

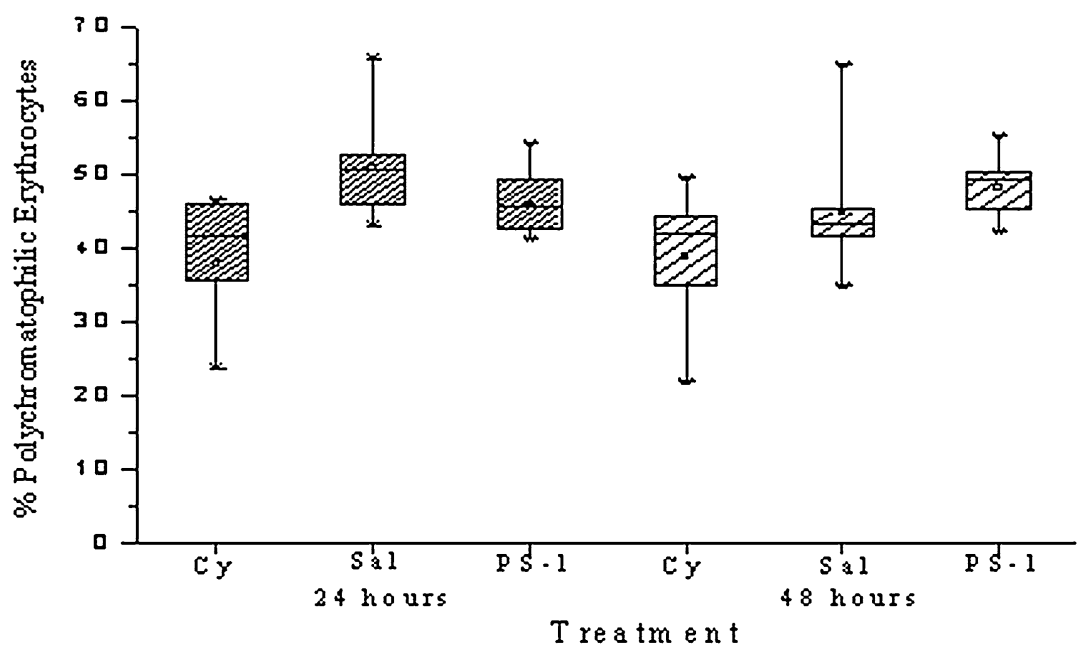

Fig. 1. The effects of endovenously administered phylloseptin-1 (PS-1) on bone marrow polychromatophilic erythrocytes 24 and 48 h after injection. Mice $(n=8)$ were treated with a bolus dose of PS-1 $(4 \mathrm{mg} / \mathrm{kg})$, or $33 \mathrm{mg} / \mathrm{kg}$ cyclophosphamide $(\mathrm{Cy})$, or $0.9 \% \mathrm{NaCl}$ solution (Sal). Median, upper and lower quartiles and extreme values are shown. The effects of treatments were evaluated by the Kruskal-Wallis test, followed by Dunn's method for multiple comparisons. No statistical difference between PS-1 and control groups was found.

The inability to determine the $\mathrm{LD}_{50}$ concentration of PS-1, even after treating mice with a dose 80 -fold over its MIC, indicated no or very low toxicity (undetectable by morphology). After a systematic investigation of a single dose (10-fold higher than MIC), no quantitative or qualitative alteration was found in blood leucocytes, or in biochemical parameters of liver and kidney damage. These findings were confirmed by the absence of microscopic alterations of these organs. The examination of bone marrow cells is a sensitive way to detect cytotoxicity. In normal situations, the proportion of polychromatophilic to normochromatophilic erythrocytes in this organ is 1:1 (Rabelo-Gay, 1991). PS-1-treated mice presented an average of $50 \%$ of polychromatophilic erythrocytes, which indicates an absence of toxicity in this system.

Micronuclei are small fragments of chromatin formed when the nucleus of erythrocytes is expelled from the cell during its maturation (Evans, 1997). An increase in the number of micronuclei indicates chromosome injury (Schmid, 1975). In our study, PS1 caused no effect on the number of erythrocyte micronuclei (Fig. 2), which indicates an absence of genotoxicity.

The remarkable feature of PS-1 to kill bacteria and fungi (Leite et al., 2005) but not mammalian cells is shared with other antimicrobial peptides, including 

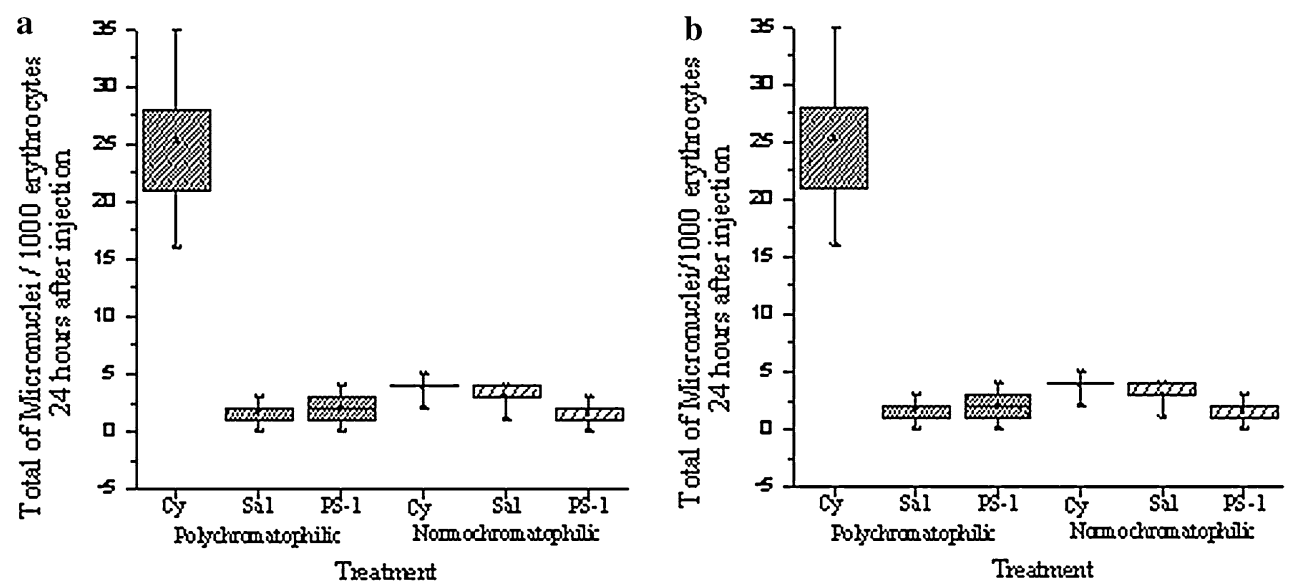

Fig. 2. Effect of phylloseptin-1 (PS-1) on Swiss mice $(n=8)$ following endovenous administration on the total micronuclei of 1000 bone marrow polychromatophilic or normochromatophilic erythrocytes after $24 \mathrm{~h}$ (a) or $48 \mathrm{~h}$ (b). Mice were treated with a bolus dose of $4 \mathrm{mg} / \mathrm{kg}$ of PS-1, or $33 \mathrm{mg} / \mathrm{kg}$ cyclophosphamide (Cy), or $0.9 \% \mathrm{NaCl}$ solution (Sal). Median, upper and lower quartiles and extreme values are shown. The effects of the drug were evaluated by the Kruskal-Wallis test, followed by Dunn's method for multiple comparisons. While Cy caused an increase in polychromatophilic ( 24 and $48 \mathrm{~h}$, both $p=0.001)$ and normochromatophilic erythrocytes $(48 \mathrm{~h}, p=0.001)$, no statistical difference was found between PS-1 and control groups.
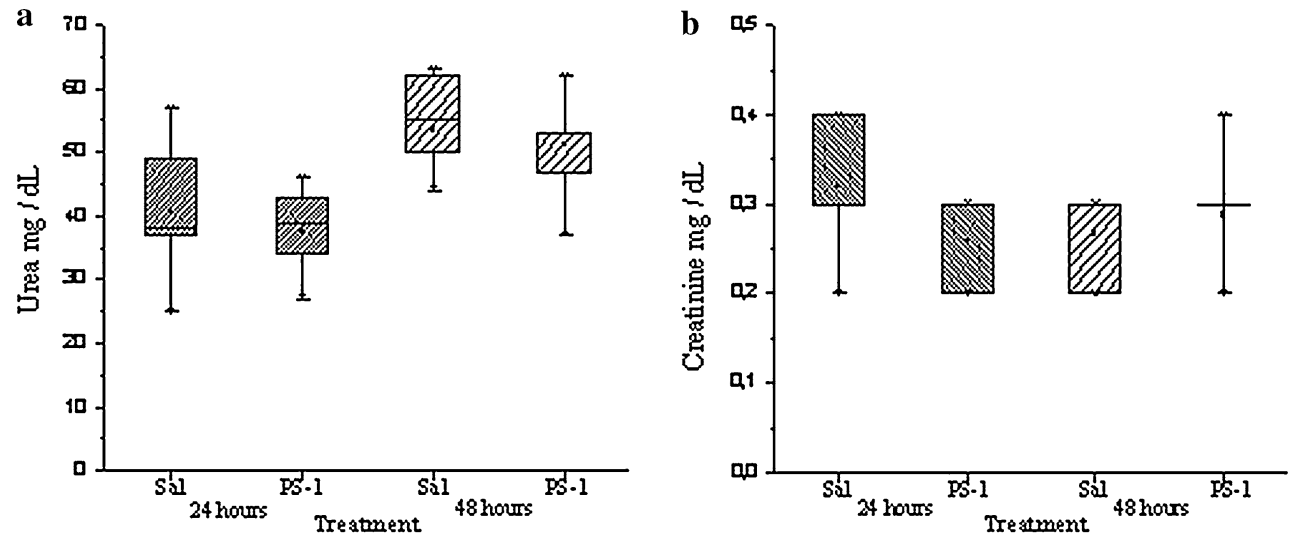

Fig. 3. Effect of phylloseptin-1 (PS-1) (4 mg/kg), or $0.9 \% \mathrm{NaCl}$ solution (Sal), endovenously administered to Swiss mice $(n=8)$, on blood urea (a), and creatinine (b) concentrations, 24 or $48 \mathrm{~h}$ after injection. Median, upper and lower quartiles are shown. The results were evaluated by the Kruskal-Wallis test, followed by the Dunn's method for multiple comparisons, and showed no statistical difference between PS-1 treated and control mice.

cecropins (Steiner et al., 1981), magainins (Andrès and Dimarcq, 2004), and dermaseptins (Krugliak et al., 2000). These peptides vary considerably in their chain length and structure, but have cationic properties in common. This feature could explain the selectivity of these antimicrobial peptides towards microorganisms, which usually are more negatively charged than mammalian cells (Sitaram and Nagaraj, 1999). This selectivity also depends on the characteristics of the amino acid sequence of the peptide, including the hydrophobic moment, isoelectric point and helicicity, as shown by Blondelle and Houghten (1991).
As suggested by Leite et al. (2005) the first target of PS-1 is the anionic plasma membrane of microorganisms. The association resulting in severe membrane alteration leads progressively to increased permeability and cell lysis. The absence of detectable toxicity of PS-1 to mouse cells and tissues could reflect its low interaction with cell plasma membrane, due to a high content of cationic lipids as cholesterol (Goluszko and Nowicki, 2005; Tomasinsig et al., 2006). Our findings indicate that the low selectivity of PS-1 to mammalian cell membranes is an important feature for explaining its low toxicity. 

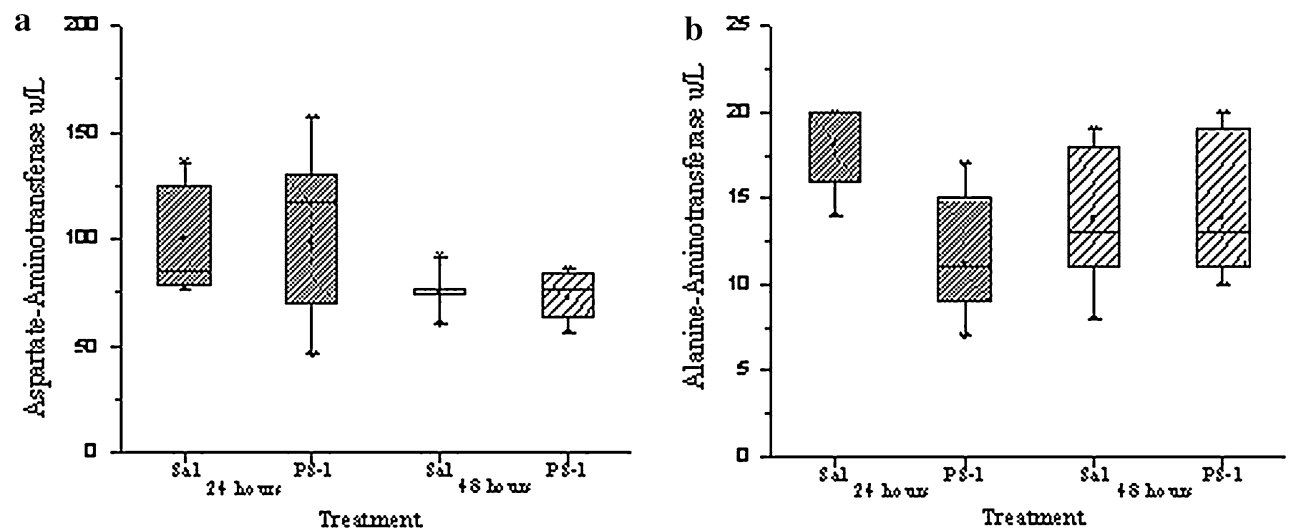

Fig. 4. Effect of phylloseptin-1 (PS-1) (4 mg/kg), or $0.9 \% \mathrm{NaCl}$ solution (Sal), endovenously administered to Swiss mice $(n=8)$ on aspartateaminotransferase (a), and alanine-aminotransferase (b) concentrations, 24 or $48 \mathrm{~h}$ after injection. Median, upper and lower quartiles are shown. Results were tested by the Kruskal-Wallis test, followed by the Dunn's method to multiple comparisons, and showed no statistical differences between PS-1 treated and control mice.
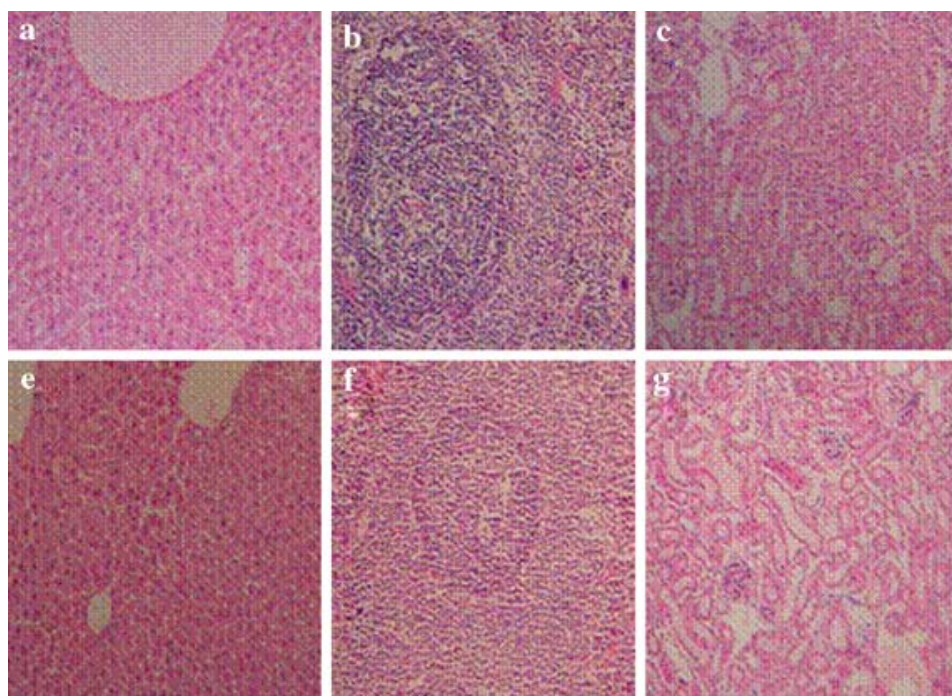
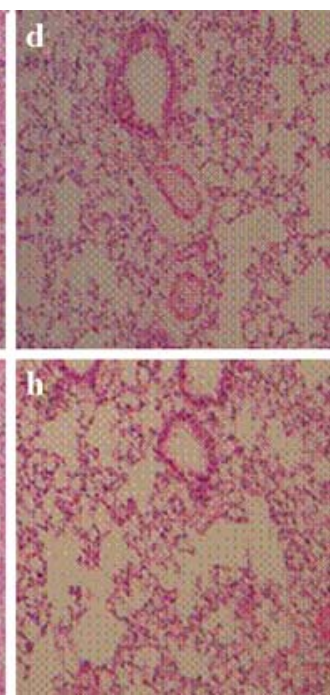

Fig. 5. Comparison between the histology of liver (a), spleen (b), kidney (c), and lung (d) from mice treated with phylloseptin-1, and the equivalent organs from mice treated with $0.9 \%$ saline solution $(\mathrm{e}-\mathrm{-h})$. All pictures refer to mice killed 7 days after treatment. Light microscopy evaluation of these organs showed no detectable morphological changes between the two groups. Hematoxilin and eosin staining, used with $100 \times$ magnification.

The broad-spectrum activity of antimicrobial peptides produced by amphibians and the enormous variability of these animals in nature make them important potential source of antibiotics for human use. We have previously showed that PS-1 is active against Gram-positive and Gram-negative bacteria, and displayed no toxic effect in an in vitro system (Leite et al., 2005). We now show, in an in vivo model, no evidence of toxicity for PS-1, using a concentration 10 -fold over that providing antimicrobial effect. The use of a single dose is an accepted procedure for preliminary toxicity tests of new compounds in animals, according to the WHO Manual of Good Laboratory Practices (WHO, 2001).

These findings may provide novel templates from which new compounds may be developed to widen the strategies for the treatment of infections, 
particularly those caused by pathogens resistant to conventional antimicrobial agents. Our present results represent a step forward a possible future use of PS-1 in humans and animals.

\section{ACKNOWLEDGMENTS}

This work was supported by the Brazilian Conselho Nacional de Desenvolvimento Científico e Tecnológico. We are grateful to Centro Universitário de Brasília (UniCEUB) for the donation of the mice used in this research.

\section{REFERENCES}

Ambroggio, E. E., Separovic, F., Bowie, J. H., Fidelio, G. D. and Bagatolli, L. A.: 2005, Biophys. J. 89, 1874-1881.

Andrès, E. and Dimarcq, J. L.: 2004, Rev. Med. Interne 25, 629635.

Apponyi, M. A., Pukala, T. L., Brinkworth, C. S., Maselli, V. M., Bowie, J. H., Tyler, M. J., Booker, G. W., Wallace, J. C., Carver, J. A., Separovic, F., Doyle, J. and Llewellyn, L. E.: 2004, Peptides 25, 1035-1054.

Black, M. T. and Hodgson, J.: 2005, Adv. Drug Deliv. Rev. 57, $1528-1538$.

Blondelle, S. E. and Houghten, R. A.: 1991, Biochemistry 30, 46714678.

Brand, G. D., Leite, J. R. S. A., Silva, L. P., Albuquerque, S., Prates, M. V., Azevedo, R. B., Carregaro, V., Silva, J. S., Sá, V. C. L., Brandão, R. A. and Bloch, C. Jr.: 2002, J. Biol. Chem. 277, 49332-49340.

Bolliger, A. P.: 2004, Vet. Clin. Pathol. 33, 58-67.

Brillard, J. P. and Mcdaniel, G. R.: 1985, Poult. Sci. 64, 155-158.

Chen, T., Farragher, S., Bjourson, A. J., Orr, D. F., Rao, P. and Shaw, C.: 2003, Biochem. J. 371, 125-130

Chen, T., Xue, Y., Zhou, M. and Shaw, C.: 2005, Peptides 26, $377-$ 383.

Clark, G.: 1980, Stained Procedures, 4th ed., Williams \& Wilkins, Baltimore, London.

Colvin, M. and Chabner, B. A.: 1990, in: Chabner, B. A., Collins, J. M. (eds.), Cancer Chemotherapy: Principles and Practices, J.B. Lippencott, Philadelphia, California, pp. 276-313.

Cunha Filho, G. A., Schwartz, C. A., Resck, I. S., Murta, M. M., Lemos, S. S., Castro, M. S., Kyaw, C., Pires, O. R. Jr., Leite, J. R. S. A., Bloch, C. Jr. and Schwartz, E. F.: 2005, Toxicon $45,777-782$.
Evans, H. J.: 1997, Mutat. Res. 392, 5-10.

Glantz, S. A.: 1992, Primer of Biostatistics, McGraw Hill, New York.

Goluszko, P. and Nowicki, B.: 2005, Infect. Immun. 73, 7791-7796.

Hancock, R. E. W. and Diamond, G.: 2000, Trends Microbiol. 8, 402-410.

Krugliak, M., Feder, R., Vadim, Y., Zolotarev, L. G., Dagan, A., Ginsburg, H. and Mor, A.: 2000, Antimicrob. Agents Chemother. 44, 2442-2451.

Leite, J. R. S. A., Silva, L. P., Rodrigues, M. I. S., Prates, M. V., Brand, G. D., Lacava, B. M., Azevedo, R. B., Bocca, A. L., Albuquerquee, S. and Bloch, C. Jr.: 2005, Peptides 26, 565573.

Merrifield, R. B. J.: 1963, Chem. Soc. 85, 2149-2156.

Matsuzaki, K.: 1999, Biochim. Biophys. Acta 1462, 1-10.

Mor, A., Nguyen, V. H., Delfour, A., Migliore, S. D. and Nicolas, P.: 1991, Biochemistry 30, 8824-8830.

Moura, R. A. A. (ed.): 1982, in Técnicas de Laboratório, Ed. Atheneu, Rio de Janeiro, RJ, pp. 77-119.

Ownby, C. L., Powell, J. R., Jiang, M. S. and Fletcher, J. E.: 1997, Toxicon 35, 67-80.

Peschel, A.: 2002, Trends Microbiol. 10, 179-186.

Rabelo-Gay, M. N.: 1991, in: Rabelo-Gay, M. N., Rodrigues, M. A. L. R., Monteleone-Neto, R. (eds.), Mutagênese, teratogênese e carcinogênese: métodos e critérios de avaliação, Sociedade Brasileira de Genética, Ribeirão Preto, São Paulo, pp. 83-90.

Schmid, W.: 1975, Mutat. Res. 31, 9-15.

Silva, L. P.: 2004, Lett. Drug Design Discov. 3, 230-236.

Sitaram, N. and Nagaraj, R.: 1999, Biochim. Biophys. Acta 1462, $29-54$.

Shiri, J., Navon-Venezia, S., Feder, R., Gaidukov, L., Carmeli, Y. and Mor, A.: 2002, Antimicrob. Agents Chemother. 46, 689694.

Stark, M., Liu, L. P. and Deber, C. M.: 2002, Antimicrob. Agents Chemother. 46, 3585-3590.

Steiner, H., Hultmark, D., Engstrom, A., Bennich, H. and Boman, H. G.: 1981, Nature 292, 246-248.

Tomasinsig, L., Skerlavaj, B., Papo, N., Giabbai, B., Shai, Y. and Zanetti, M.: 2006, J. Biol. Chem. 281, 383-391.

Vanhoye, D., Bruston, F., Nicolas, P. and Amiche, M.: 2003, Eur. J. Biochem. 270, 2068-2081.

World Health Organization: 2000, Drug resistance threatens to reverse medical progress, Press Release WHO/41.12.

World Health Organization: 2001, Good Laboratory Practice (GLP) UNDP/World Bank/WHO Special Programme for Research and Training in Tropical Diseases (document no. TDR/PRD/GLP/01.1B). 